\title{
Pengaruh Pemberian Antioksidan Vitamin C Dan E Terhadap Konsentrasi Spermatozoa Mencit (Mus Musculus) Yang Dipapar Asap Rokok
}

\author{
Ervina Wati Harahap ${ }^{1}$, Normalina Sandora ${ }^{2}$, Winarto ${ }^{3}$
}

\begin{abstract}
Free radical that are released in cigarette smoke, believed to play an important role in male infertility. The free radical produces Reactive Oxygen Species (ROS) that is found increased in male smokers. ROS is one of the free radicals component can be neutralized by vitamin $\mathrm{C}$ and $\mathrm{E}$ as an antioxidant. This study using those agents to the fifteen minutes half piece cigarette to expose mice and count their sperm as the fertilility parameter. The research design used was post test-only control group with twenty mice were divided into five groups. A group of no smoke exposed was categorized as a baseline control, the exposed groups were consisted of one group without antioxidant, one group with vitamin $\mathrm{C}$ treatment, a group of vitamin E treatment and at last the combination of vitamin $\mathrm{C}$ and $\mathrm{E}$. All groups were treated for fourteen days. The results were analyzed using oneway ANOVA with $\mathrm{p}<0.05$. It is obviously proven that the combination of vitamin $\mathrm{C}$ and vitamin $\mathrm{E}$ treatment on the usual dose gave the highest sperm count compared to other groups.
\end{abstract}

Keyword: Vitamin C, vitamin E, cigarette smoke, consentration of sperm

Infertilitas merupakan masalah penting yang perlu diperhatikan di seluruh dunia maupun Indonesia. ${ }^{1} \mathrm{Hal}$ ini tampak dari besarnya jumlah pasangan usia subur yang mengalami infertilitas sekitar 15-20\% (kurang lebih lima puluh juta pasangan infertil) baik dari faktor pria maupun wanita. Diperkirakan dua juta pasangan infertil setiap tahunnya akan meningkat. ${ }^{2}$

Menurut WHO sekitar $40 \%$ dari kasus infertilitas berasal dari faktor pria, dengan dua kelompok penyebab yaitu disfungsi ereksi (60\%) dan kualitas ejakulat yang buruk (40\%). ${ }^{2}$ Pada kasuskasus infertilitas, hasil analisis semen menunjukkan bahwa penyebab infertil terbanyak adalah gangguan konsentrasi, gangguan morfologi dan motilitas spermatozoa. ${ }^{3}$

\footnotetext{
1 Coresponding Author. Mahasiswa Fakultas Kedokteran Universitas Riau, Jl.Diponegoro No.1 Pekanbaru

2 Bagian Biologi Fakultas Kedokteran Universitas Riau

3 Bagian Histologi Fakultas Kedokteran Universitas Riau
}

Dalam ilmu kesehatan reproduksi, Reactive Oxygen Species (ROS) menjadi salah satu mediator penting terjadinya infertilitas. Terbentuknya ROS dipicu oleh faktor lingkungan seperti polusi dan faktor gaya hidup seperti kebiasaan merokok. ${ }^{4}$

Rokok adalah hasil olahan tembakau termasuk cerutu atau bentuk lainnya yang dihasilkan dari tanaman Nicotiana tabacum, Nicotiana rustica. ${ }^{5}$ Rokok merupakan masalah kesehatan di berbagai negara. Indonesia menduduki urutan ke tiga di dunia setelah Cina dan India sebagai negara dengan jumlah perokok terbanyak yaitu sebanyak $28 \%$ (65 juta penduduk Indonesia yang menghabiskan 225 milyar batang pertahun). ${ }^{6}$

Masalah kesehatan tersebut terkait dengan kandungan radikal bebas yang terdapat di dalam asap rokok. Dalam satu kali hisap, diperkirakan 1014 molekul radikal bebas masuk ke dalam tubuh. Asap rokok mengandung \pm 4000 senyawa kimia dengan 60 senyawa kimia telah diidentifikasi sebagai penyebab kanker dan bersifat genotoksik. Senyawa kimia tersebut beredar dalam pembuluh darah testis 
merusak spermatozoa dengan efek sitotoksiknya. ${ }^{5}$ Senyawa kimia tersebut terdiri dari nikotin, tar, karbon monoksida, aseton, arsenik, amoniak, hidrogen sianida dan sebagainya. ${ }^{2,5}$

Antioksidan adalah substansi yang diperlukan tubuh untuk menetralisir radikal bebas dan mencegah kerusakan yang ditimbulkannya. Antioksidan menstabilkan radikal bebas dengan melengkapi kekurangan elektron yang dimiliki radikal bebas dan menghambat terjadinya reaksi berantai dari pembentukan radikal bebas yang dapat menimbulkan stres oksidatif. ${ }^{6}$ Stres oksidatif adalah ketidakseimbangan antara radikal bebas dan antioksidan yang dipicu oleh dua kondisi umum yaitu kurangnya antioksidan dan kelebihan produksi radikal bebas. ${ }^{5}$ Ketersedian antioksidan di dalam tubuh harus cukup menyeimbangkan radikal bebas dan kadang ditingkatkan melalui sistem antioksidan eksogen. ${ }^{6}$

Vitamin C dan E sebagai antioksidan eksogen dapat menghentikan reaksi berantai radikal bebas. Vitamin E mendonorkan elektron kepada radikal bebas, selanjutnya berubah menjadi vitamin $\mathrm{E}$ radikal yang dinetralisir oleh vitamin $\mathrm{C}$ melalui proses pemutusan reaksi radikal bebas menjadi vitamin E yang dapat berfungsi kembali sebagai antioksidan. Mekanisme kerja yang berbeda tersebut, jika kedua vitamin ini digunakan bersamaan akan dapat menghambat aktivitas radikal bebas. $^{7}$

Hal ini terbukti dari penelitian Cita (2006) menunjukkan bahwa rerata konsentrasi spermatozoa pada mencit yang diberi paparan asap rokok dan vitamin $\mathrm{C}$ lebih tinggi dibandingkan rerata konsentrasi spermatozoa mencit yang diberi paparan asap rokok tanpa pemberian vitamin C. ${ }^{8}$ Demikian juga penelitian Titisari (2003) bahwa vitamin C dengan dosis $0,012 \mathrm{mg} / \mathrm{gBB} /$ hari yang diberikan pada mencit dapat mengurangi efek radikal bebas dari ekstrak tembakau, yaitu dengan meningkatnya konsentrasi, motilitas dan morfologi spermatozoa. ${ }^{9}$

Penelitian Sari (2006) menunjukkan bahwa pemberian vitamin E dapat meningkatkan konsentrasi spermatozoa mencit yang diberi paparan asap rokok. ${ }^{10}$ Penelitian Siti (2006) juga membuktikan bahwa pemberian vitamin E dapat menangkal radikal bebas dalam mempertahankan kualitas spermatogenesis mencit yang diberi paparan asap rokok. ${ }^{11}$

Iswara (2009) menggunakan kombinasi vitamin $\mathrm{C}$ dan E pada tikus yang terpapar alletrin ternyata dapat meningkatkan konsentrasi, motilitas dan morfologi spermatozoa tikus. ${ }^{12}$ Pada manusia, Ardini (2005) menemukan bahwa kombinasi vitamin C dan E mampu menghambat terjadinya peroksidasi lipid pada pasien preeklamsia. ${ }^{13}$

Berdasarkan hal di atas maka dirasa perlu diteliti tentang pengaruh antioksidan berupa vitamin $\mathrm{C}$, vitamin $\mathrm{E}$ dan kombinasi vitamin $\mathrm{C}$ dan $\mathrm{E}$ terhadap konsentrasi spermatozoa mencit (Mus musculus) yang dipapar asap rokok.

Tujuan penelitian ini adalah untuk mengetahui pengaruh pemberian antioksidan vitamin $\mathrm{C}$ dan $\mathrm{E}$ terhadap konsentrasi spermatozoa mencit (Mus musculus) yang dipapar asap rokok.

\section{METODE}

Penelitian ini merupakan penelitian eksperimental dengan post test only control group design yang dilakukan pada bulan April 2011 di Laboratorium Farmakologi Fakultas Kedokteran Universitas Riau. Sampel yang digunakan dalam penelitian ini adalah mencit (Mus musculus) jantan berumur 2-3 bulan dan memenuhi kriteria hewan uji sehat yang diperoleh dari Sekolah Tinggi Ilmu Farmasi (STIFAR) Pekanbaru. Kriteria hewan uji sehat yaitu penampilan fisik tidak tampak kurus, bentuk badan simetris, bergerak gesit dan berat badan selama proses adaptasi tidak menurun lebih dari $10 \%$ berat badan semula. ${ }^{14}$

Penentuan jumlah sampel minimal untuk masing-masing kelompok berdasarkan rumus Faraday adalah $\mathrm{t}(\mathrm{r}-1) \geq 15$, di mana $\mathrm{t}=5=$ jumlah kelompok percobaan dan $\mathrm{r}=$ jumlah hewan coba. ${ }^{15}$

$$
\begin{aligned}
& 5(\mathrm{r}-1) \geq 15 \\
& \mathrm{r}-1 \geq 3 \\
& \mathrm{r} \geq 4
\end{aligned}
$$

\section{Alat dan Bahan}

Alat yang digunakan adalah timbangan, kandang hewan coba, kandang khusus pengasapan $30 \times 22 \times 19 \mathrm{~cm}$, mikroskop cahaya, haemositometer 
neubaeur, mikropipet, tip, deckglass, hand counter, tabung ependorf, vortex, papan fiksasi dan minor set, smoking pump, sonde lambung dan spuit $1 \mathrm{cc}$.

Bahan yang digunakan adalah makanan dan minuman mencit berupa pelet dan aquades, antioksidan (Vitamin $\mathrm{C}$ dan vitamin $\mathrm{E}$ ), rokok, $\mathrm{NaCl}$ fisiologis, minyak nabati (VCO) dan eter.

\section{Prosedur}

\section{Persiapan penelitian}

Menyiapkan hewan uji sebanyak 30 ekor mencit jantan, menyiapkan kandang perlakuan yang terbuat dari bak plastik dan kandang khusus pengasapan berukuran $30 \times 22 \times 19 \mathrm{~cm}$ serta menyiapkan alat-alat dan bahan yang digunakan dalam pemberian perlakuan.

\section{Pemilihan hewan coba}

Penelitian ini dilakukan pada 30 ekor mencit jantan yang berumur 2-3 bulan dengan berat badan rata-rata 20-25 gram/ekor setelah dilakukan penimbangan berat badan awal mencit. Mencit yang digunakan sebagai hewan coba adalah mencit jantan yang memenuhi kriteria hewan uji sehat. Hewan uji dikatakan sehat apabila penampilan fisik tidak tampak kurus, bentuk badan simetris, bergerak gesit, berat badan selama proses adaptasi tidak menurun lebih dari $10 \%$ berat badan semula. ${ }^{14}$

\section{Pemeliharaan}

Mencit diadaptasikan dengan lingkungan baru selama satu minggu. Alas kandang diberi sekam kayu untuk menyerap kotoran. Kandang diletakkan di ruangan yang berventilasi cukup pada suhu ruangan dengan sirkulasi udara yang baik. Mencit diberi makan dan minum ad libitium berupa pelet sebanyak $4-5 \mathrm{~g} /$ hari dan aquades. ${ }^{14}$

\section{Penentuan dosis pemberian vitamin $C$ dan $E$}

a. Dosis vitamin C hari. $^{12}$

Dosis pencegahan untuk manusia $=100 \mathrm{mg} /$
Dosis konversi untuk mencit

$=0,0026 \times 100 \mathrm{mg}$

$=0,26 \mathrm{mg} / 20 \mathrm{gBB} / \mathrm{hari}$

b. Dosis vitamin E

Dosis pencegahan untuk manusia

$=120 \mathrm{IU} /$ hari $=80 \mathrm{mg} /$ hari ${ }^{12}$

Dosis konversi untuk mencit

$=0,0026 \times 80 \mathrm{mg}$

$=0,21 \mathrm{mg} / 20 \mathrm{gBB} / \mathrm{hari}$

\section{Pembagian kelompok perlakuan}

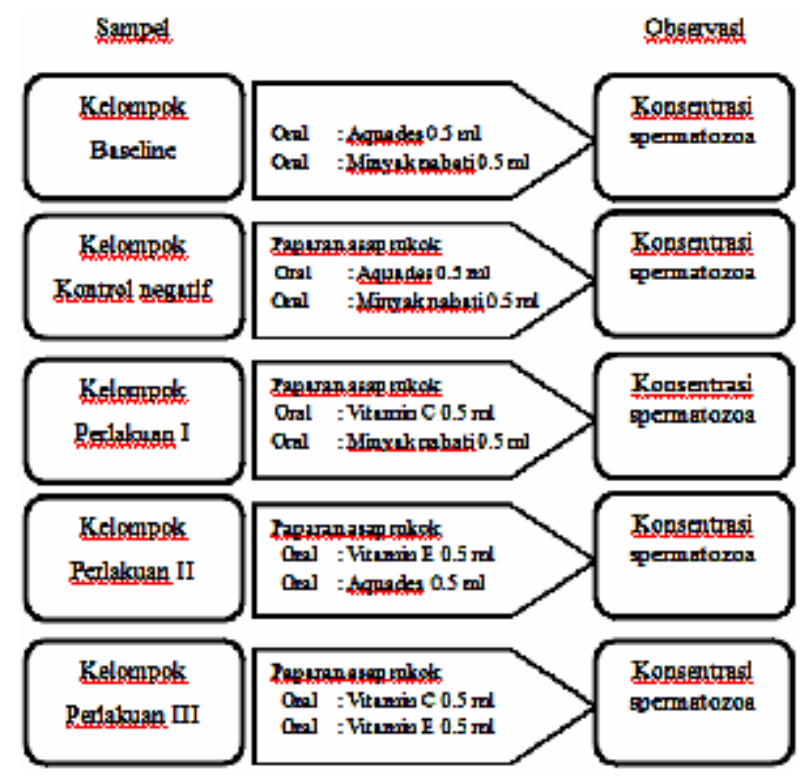

\section{Memberi tanda pada mencit}

Sebelum melakukan perlakuan, mencit diberi tanda pada daerah kepala, punggung dan ekor. Tanda yang diberi setiap kelompok dengan warna yang berbeda-beda dan letak tanda tersebut dibedakan pada setiap kelompok sesuai dengan waktu perlakuan. Kelompok baseline diberi tanda berwarna merah (४), kontrol negatif diberi tanda berwarna kuning $(\diamond)$, kelompok perlakuan I diberi tanda berwarna biru (৬), kelompok perlakuan II diberi tanda berwarna hijau (৬) dan kelompok perlakuan III diberi tanda berwarna hitam (৬). 
Tanda yang diberi pada daerah yang berbeda bertujuan untuk membedakan waktu pemberian perlakuan, yaitu; kelompok yang diberi tanda di daerah kepala mendapat perlakuan pada pukul 09.00-10.00 wib, Kelompok yang diberi tanda di daerah punggung mendapat perlakuan pada pukul 10.00-11.00 wib dan kelompok yang diberi tanda di daerah ekor mendapat perlakuan pada pukul 11.0012.00 wib.

\section{Cara pemberian perlakuan}

Kelompok perlakuan baseline diberi aquades sebanyak $0,5 \mathrm{ml}$ dan minyak nabati $0,5 \mathrm{ml}$ tanpa dipapar asap rokok. Pada kelompok perlakuan kontrol negatif diberi paparan asap rokok sebanyak setengah batang tanpa diberi antioksidan dan diberi aquades $0,5 \mathrm{ml}$ dan minyak nabati $0,5 \mathrm{ml}$. Kelompok perlakuan I diberi paparan asap rokok setelah itu diberi antioksidan vitamin $\mathrm{C}$ dengan dosis $0,26 \mathrm{mg} /$ $20 \mathrm{gBB} /$ hari yang dilarutkan dengan aquades sebanyak $0,5 \mathrm{ml}$. Kelompok perlakuan II diberi paparan asap rokok setelah itu diberi antioksidan vitamin $\mathrm{E}$ dengan dosis $0,21 \mathrm{mg} / 20 \mathrm{gBB} / \mathrm{hari}$ yang dilarutkan dengan minyak nabati hingga menjadi 0,5 $\mathrm{ml}$. Kelompok perlakuan III diberi paparan asap rokok setelah itu diberi antioksidan vitamin $\mathrm{C}$ dengan dosis $0,26 \mathrm{mg} / 20 \mathrm{gBB} / \mathrm{hari}$ yang dilarutkan dengan aquades sebanyak $0,5 \mathrm{ml}$ dan $\mathrm{E}$ dengan dosis $0,21 \mathrm{mg} / 20 \mathrm{gBB} / \mathrm{hari}$ yang dilarutkan dengan minyak nabati hingga menjadi $0,5 \mathrm{ml}$. Pemberian vitamin $\mathrm{C}$ dan $\mathrm{E}$ diberikan secara oral dengan menggunakan sonde lambung.

\section{Pemaparan dan terminasi mencit}

Sampel yang dipapar pada masing-masing kelompok diambil secara random, sesuai dengan mencit yang telah diberi tanda. Pemaparan asap rokok dilakukan satu kali sehari selama 14 hari, masing-masing sebanyak setengah batang rokok dengan menggunakan smoking pump yaitu spuit 10 cc sebagai pompa asap rokok. Lama pemaparan setengah batang rokok \pm 15 menit. Pemaparan dilakukan dengan cara memasukkan delapan ekor mencit kedalam kandang khusus pengasapan yang berukuran 30x22×19 $\mathrm{cm}$. Setelah dipapar asap rokok, kelompok tersebut di diberi perlakuan sesuai masing-masing kelompok perlakuan.
Pada akhir perlakuan, tepatnya hari ke 15 mencit tersebut diterminasi dengan cara membius mencit dengan menggunakan eter, mencit yang telah dibius diletakkan di papan fiksasi untuk dibedah. Pembedahan dilakukan dengan menggunakan alat bedah, kemudian organ testis beserta epididimis sebelah kiri diidentifikasi yang diambil dengan cara memisahkan bagian proksimal corpus epididimis dan bagian distal vas deferens.

\section{Prosedur pengambilan dan perhitungan spermatozoa}

Setelah dibersihkan dari lemak yang melekat, bagian proksimal kauda epididimis dipotong sedikit dengan gunting lalu kauda ditekan dengan perlahan sehingga sekresi epididimis keluar yang dimasukkan kedalam tabung ependorf yang berisi $1 \mathrm{ml} \mathrm{NaCl}$ $0,9 \% .^{50}$

Penghitungan konsentrasi spermatozoa dilakukan dengan cara sebagai berikut: Suspensi spermatozoa yang telah diperoleh terlebih dahulu dihomogenkan dengan menggunakan vortex. Selanjutnya diambil sebanyak $10 \mu \mathrm{l}$ dan diletakkan diatas kamar hitung improved Neubauer (hemositometer) dan selanjutnya ditutup dengan deckglass. ${ }^{16}$

Pemeriksaan dilakukan dibawah mikroskop cahaya dengan pembesaran 400x dan dihitung konsentrasi spermatozoa pada lima kotak yang bertanda warna hitam. (Gambar 3.3).
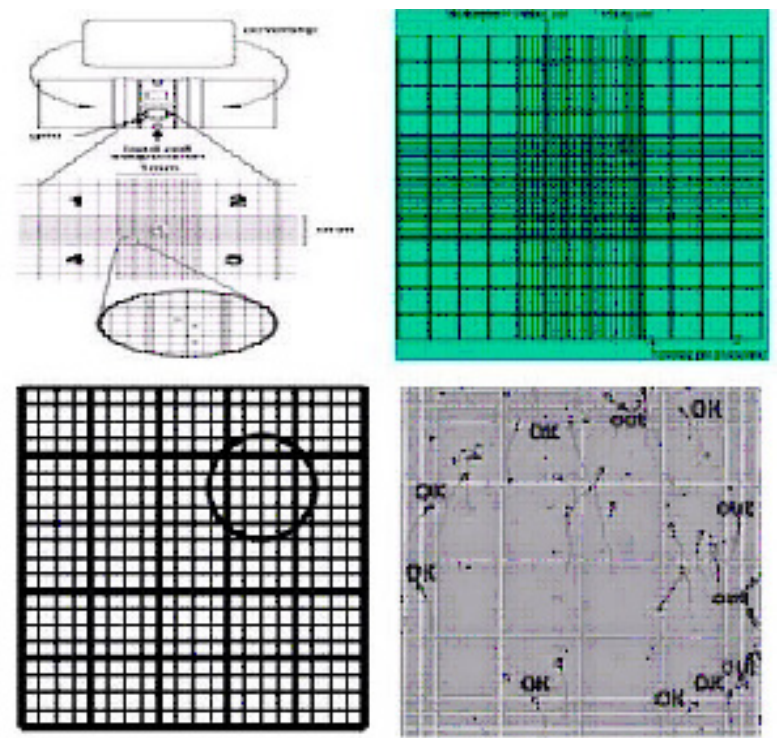


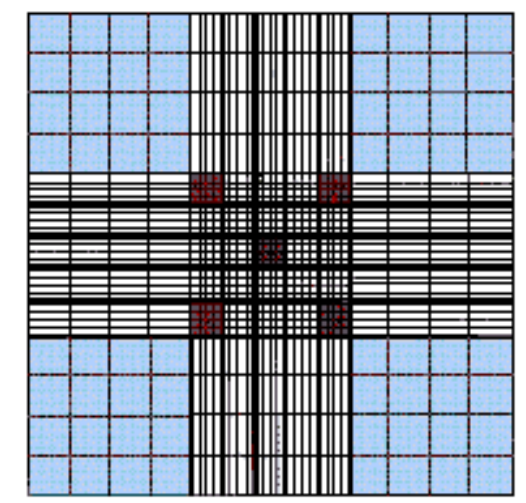

Gambar 3.3 Kamar hitung improved Neubauer yang digunakan untuk menghitung dan mengamati spermatozoon

\section{Analisis data}

Analisis statistik dilakukan menggunakan program komputer untuk membandingkan konsentrasi spermatozoa antara berbagai kelompok perlakuan. Data hasil penelitian diuji normalitas dan homogenitasnya. Data selanjutnya diolah dengan menggunakan metode One Way Anova dan dilanjutkan dengan uji post hoc untuk mengetahui perbedaan antar tiap perlakuan Hasil dianggap bermakna jika $\mathrm{p}<0,05$.

\section{HASIL}

Hasil penelitian ini menunjukkan bahwa kelompok $\mathrm{K}(-)$ terjadi penurunan konsentrasi spermatozoa dibandingkan dengan kelompok baseline yang dapat dilihat pada Tabel 1 .

Tabel 1. Rata-rata pengaruh perlakuan terhadap konsentrasi spermatozoa $\left(10^{5}\right.$ spermatozoa/ml)

\begin{tabular}{llllll}
\hline $\begin{array}{l}\text { Nomor } \\
\text { Sampel }\end{array}$ & \multicolumn{2}{l}{ Konsentrasi Spermatozoa } \\
Petlakuan
\end{tabular}

\section{Keterangan}

Baseline : kelompok tanpa paparan asap rokok + aquades dan minyak nabati

K- $\quad$ : kelompok paparan asap rokok + aquades dan minyak nabati

$\mathrm{P}_{1} \quad$ : kelompok paparan asap rokok + vitamin $\mathrm{C}$ dan minyak nabati

$\mathrm{P}_{2} \quad$ : kelompok paparan asap rokok + vitamin $\mathrm{E}$ dan aquades

$\mathrm{P}_{3} \quad:$ kelompok paparan asap rokok + vitamin $\mathrm{C}$ dan $\mathrm{E}$

Berdasarkan Tabel 1 menunjukkan hasil bahwa konsentrasi spermatozoa meningkat pada semua kelompok $\mathrm{P}_{1}(17,75), \mathrm{P}_{2}(18,75)$ dan $\mathrm{P}_{3}(22,00)$ dibandingkan dengan kelompok kontrol negatif $(14,50)$. Namun, kelompok $\mathrm{P}_{3}$ menunjukkan hasil yang lebih tinggi dibandingkan $\mathrm{P}_{1}$ dan $\mathrm{P}_{2}$.

Berdasarkan uji statistik dapat dilihat bahwa kelompok baseline memiliki perbedaan bermakna dengan kelompok $\mathrm{K}(-)$ yang nilai $\mathrm{p}=0,000$ yang berarti terdapat penurunan konsentrasi spermatozoa pada mencit yang dipapar asap rokok. Antara kelompok $\mathrm{K}(-)$ dengan kelompok $\mathrm{P}_{1}, \mathrm{P}_{2}$ dan $\mathrm{P}_{3}$ diperoleh nilai $\mathrm{p}<0,05$ yang menunjukkan bahwa kelompok $\mathrm{P}_{1}, \mathrm{P}_{2}$ dan $\mathrm{P}_{3}$ memiliki efek meningkatkan konsentrasi spermatozoa. Namun, berdasarkan rerata konsentrasi spermatozoa diantara kelompok yang diberi antioksidan tersebut yang paling bermakna adalah kelompok $\mathrm{P}_{3}$, diikuti kelompok $\mathrm{P}_{2}$ dan $\mathrm{P}_{1} \mathrm{P}_{1}$ dan $\mathrm{P}_{2}$ tidak memiliki perbedaan yang 
bermakna secara statistik dengan nilai $\mathrm{p}>0.05$, hal ini menunjukkan efek yang dihasilkan antara vitamin $\mathrm{C}$ dan vitamin $\mathrm{E}$ dalam meningkatkan jumlah spermatozoa pada mencit yang terpapar asap rokok adalah sebanding. Hasilnya dapat dilihat pada Tabel 2

Tabel 2. Hasil analisis Post Hoc pada berbagai perlakuan

\begin{tabular}{|c|c|}
\hline Perbandingan berbagai perlakuan & Signifikansi \\
\hline Baseline vs $\mathrm{K}(-)$ & $0,000^{*}$ \\
\hline Baseline vs $P_{1}$ & $0,000^{*}$ \\
\hline Baseline vs $\mathrm{P}_{2}$ & $0,000^{*}$ \\
\hline Baseline vs $\mathrm{P}_{3}$ & $0,000^{*}$ \\
\hline $\mathrm{K}(-) \quad$ vs $\mathrm{P}_{1}$ & $0,004 *$ \\
\hline vs $\mathrm{P}_{2}$ & $0,000^{*}$ \\
\hline vs $P_{3}$ & $0,000 *$ \\
\hline vs $\mathrm{P}_{2}$ & 0,304 \\
\hline vs $P_{3}$ & $0,000^{*}$ \\
\hline vs $P_{3}$ & $0,004 *$ \\
\hline
\end{tabular}

Ket :

$$
\begin{aligned}
& *(\mathrm{p}<0,05) \quad: \text { terdapat perbedaan yang } \\
& \text { bermakna secara statistik } \\
&(\mathrm{p}>0,05) \quad: \begin{array}{l}
\text { tidak ada perbedaan yang } \\
\text { bermakna secara statistik }
\end{array}
\end{aligned}
$$

\section{PEMBAHASAN}

Hasil penelitian ini menunjukkan bahwa kelompok $\mathrm{K}(-)$ terjadi penurunan konsentrasi spermatozoa dibandingkan dengan kelompok baseline. Hal ini dapat dihubungkan dengan asap rokok yang mengandung berbagai senyawa oksigen reaktif yang merupakan sumber utama radikal bebas yang berasal dari lingkungan. ${ }^{4}$ Penelitian Hosseinzadeh (2007) menunjukkan bahwa pada pria yang merokok, memiliki kadar ROS dalam semen yang lebih tinggi dari pria yang bukan perokok. ${ }^{17}$ Penelitian Sukmaningsih (2009) pada mencit yang dipapar asap rokok mengalami penurunan jumlah spermatosit dan spermatid tubulus seminiferus. ${ }^{18}$

Peningkatan ROS berperan dalam proses fisiologis dan patologis fertilitas pria. Terbukti dari penelitian Agarwal (2009) yang menunjukkan bahwa terjadi peningkatan bermakna ROS pada semen pria India yang mengalami infertil idiopatik dibandingkan dengan kelompok kontrol ${ }^{19}$ dan penelitian Agarwal (2008) pada pria infertil idiopatik memiliki kualitas semen yang rendah, kadar ROS yang tinggi dan kapasitas total antioksidan yang rendah. ${ }^{20}$

Kadar ROS yang berlebihan akan memicu terjadinya stres oksidatif. Stres oksidatif merupakan keadaan terganggunya keseimbangan antara produksi radikal bebas dengan pertahanan antioksidan di dalam tubuh. Stres oksidatif akan menginduksi terjadinya peroksidasi lipid. Peroksidasi lipid adalah oksidasi komponen lipid pada membran sel seperti fosfolipid, glikolipid, dan komponen lipid yang mengandung asam lemak tak jenuh. ${ }^{19,20}$ Membran sel spermatozoa mengandung asam lemak tak jenuh yang sangat rentan terhadap ROS. ${ }^{4}$

Stres oksidatif pada spermatozoa dapat merusak membran mitokondria. Kerusakan membran mitokondria yang diakibatkan ROS akan menyebabkan peningkatan produksi ROS sehingga menimbulkan peroksidasi lipid pada membran spermatozoa. ${ }^{4}$ Peroksidasi lipid yang diperantarai ROS dibagi menjadi tiga tahap yaitu inisiasi, propagasi, dan terminasi. ${ }^{7}$ Akhir dari reaksi berantai peroksidasi lipid berupa MDA yang merupakan indikator terjadinya stres oksidatif. Penelitian Nabila (2008) membuktikan bahwa terjadi peningkatan kadar MDA di dalam semen pada pria yang mengalami oligozoospermic dibandingkan pria yang normozoospermic. ${ }^{21}$

Selain merusak membran plasma, ROS juga 
dapat merusak integritas DNA pada nukleus spermatozoa. Kerusakan DNA akan menginduksi terjadinya apoptosis sel yang pada akhirnya menyebabkan turunnya konsentrasi spermatozoa. Penelitian ini didukung oleh penelitian Hayati (2006) yang menyatakan bahwa senyawa radikal yang menyebabkan stres oksidatif dapat memicu terjadinya peroksidasi pada lipid membran spermatozoa sehingga terjadi kerusakan membran dan penurunan integritas membran spermatozoa yang pada akhirnya berdampak terhadap penurunan konsentrasi, motilitas dan morfologi spermatozoa. ${ }^{22}$

Penghitungan konsentrasi spermatozoa menunjukkan rerata konsentrasi spermatozoa meningkat secara bermakna pada kelompok $\mathrm{P}_{1} \mathrm{P}_{2}$, dan $\mathrm{P}_{3}$ dibandingkan dengan kelompok kontrol negatif. Peningkatan konsentrasi spermatozoa terjadi karena mencit diberi perlakuan berupa antioksidan vitamin $\mathrm{C}$ dan $\mathrm{E}$. Antioksidan vitamin $\mathrm{C}$ dan $\mathrm{E}$ mampu menangkal ROS yang disebabkan oleh asap rokok yang mengandung \pm 4000 senyawa kimia, sehingga pada penelitian ini menggunakan antioksidan sebagai jalur reaksi meningkatkan konsentrasi spermatozoa yang diberikan paparan asap rokok. ${ }^{6,7}$ Antara kelompok $\mathrm{P}_{1}$ dan $\mathrm{P}_{2}$ tidak memiliki perbedaan yang bermakna. Ini menunjukkan, vitamin $\mathrm{C}$ dan $\mathrm{E}$ mempunyai kemampuan yang sama dalam menangkal radikal bebas walaupun vitamin $\mathrm{E}$ menunjukkan angka rerata yang lebih baik dalam perhitungannya, sehingga jumlah spermatozoa bisa dipertahankan.

Vitamin $\mathrm{C}$ berfungsi menetralisir radikal bebas yang terkandung dalam asap rokok. Vitamin $\mathrm{C}$ berperan sebagai kofaktor dalam sejumlah reaksi hidroksilasi dan mempunyai polaritas yang tinggi sehingga mudah larut dalam air. ${ }^{6}$ Vitamin $\mathrm{C}$ dapat langsung bereaksi dengan radikal hidroksil, superoksida dan hidrogen peroksida. Hasil penelitian yang dilakukan oleh Tengku (2008) membuktikan bahwa penambahan vitamin $\mathrm{C}$ pada mencit yang dipapar timbal asetat dapat menurunkan MDA secara bermakna. MDA merupakan indikator terjadinya stres oksidatif. ${ }^{23}$ Penelitian Cita (2006) menunjukkan bahwa rerata konsentrasi spermatozoa pada mencit yang diberi paparan asap rokok dan vitamin $\mathrm{C}$ lebih tinggi dibandingkan rerata konsentrasi spermatozoa mencit yang diberi paparan asap rokok tanpa pemberian vitamin C. ${ }^{8}$
Vitamin E bersifat lipofilik yang berfungsi melindungi membran sel terhadap peroksidasi lipid. Vitamin E mencegah peroksidasi lipid dengan mendonorkan atom hidrogen kepada radikal lipid. ${ }^{6}$ Vitamin E menghambat tahap propagasi rantai radikal dengan lipid dan membentuk lipid hidroperoksida yang stabil serta mengkonversi alfa tokoferol menjadi produk yang teroksidasi yaitu radikal alfa tokoferoksil. Radikal alfa tokoferoksil memiliki kecenderungan kecil untuk mengekstraksi sebuah atom hidrogen dari senyawa lain dan menyebarkan reaksi radikal. ${ }^{6,7}$ Penelitian Siti (2006) menunjukkan bahwa pemberian vitamin $\mathrm{E}$ dapat menangkal radikal bebas dalam mempertahankan kualitas spermatogenesis mencit yang diberi paparan asap rokok. ${ }^{11}$

Peningkatan yang tinggi dapat terlihat pada kelompok $\mathrm{P}_{3}$ yang menunjukkan bahwa pemberian kombinasi antioksidan vitamin $\mathrm{C}$ dan $\mathrm{E}$ mampu menangkal radikal bebas sehingga konsentrasi spermatozoa dapat dipertahankan lebih baik daripada pemberian satu jenis vitamin yaitu vitamin $\mathrm{C}$ maupun vitamin E saja. Hal ini sesuai teori bahwa adanya kerja sama yang sinergis dari vitamin $\mathrm{C}$ dan E yaitu menetralisir ROS yang ditimbulkan oleh asap rokok dengan cara vitamin E mendonorkan atom hidrogen kepada radikal lipid, sehingga vitamin E akan teroksidasi menjadi radikal alfa tokoferoksil yang dapat diregenerasi menjadi alfa tokoferol stabil kembali melalui proses reduksi dengan grup hidroksil dari antioksidan lain seperti vitamin C (asam askorbat). ${ }^{6,7}$ Vitamin $C$ yang reaktif akan berubah menjadi netral dengan bantuan NADPH melalui enzim NADH semidehidroaskorbat reduktase. Bahkan, radikal alfa tokoferoksil dapat berinteraksi secara langsung dengan radikal peroksi lipid, sehingga radikal alfa tokoferoksil tersebut kehilangan atom hidrogen lainnya dan menjadi tokoferil kuinon yang stabil serta teroksidasi sempurna. ${ }^{7,9}$ Hasil penelitian ini didukung oleh penelitian Iswara (2009) yang menunjukkan bahwa kombinasi vitamin $\mathrm{C}$ dan $\mathrm{E}$ dapat meningkatkan konsentrasi, motilitas dan morfologi spermatozoa tikus yang terpapar alletrin. ${ }^{12}$

\section{KESIMPULAN}

Pemberian kombinasi vitamin $\mathrm{C}$ dan vitamin $\mathrm{E}$ meningkatkan konsentrasi spermatozoa tertiggi 
dibandingkan pemberian tunggal vitamin $\mathrm{C}$ atau vitamin E pada mencit (Mus musculus) yang dipapar asap rokok.

\section{UCAPAN TERIMA KASIH}

Penulis mengucapkan terima kasih yang sebesar-besarnya kepada Fakultas Kedokteran Universitas Riau atas segala fasilitas dan kemudahan yang diberikan kepada penulis selama melaksanakan penelitian ini.

\section{DAFTAR PUSTAKA}

1. Garcia JE, Nelson LM, Wallach EE. Infertility [monograph pada internet]. Baltimore: Emedicine; 2006 [cited 2011 April 30]. Available from: http://emedicine.medscape.com/article/ 274143-overview.

2. Depkes RI. Rokok jadi masalah besar kesehatan masyarakat Indonesia, promosi kesehatan online. Mei 2004; [cited 2010 August 27]. Available from: http//www.depkes.go.id.

3. Ahmed ME, Mansour MM, Khalid KE, Yosif N, Elhasan EM, Miskeen E. Semen analysis of infertile Sudanese males in Gezira State Central Sudan. Sudanese Journal of Public Health 2009; 4: 340-344.

4. Makker K, Agarwal A, Sharma R. Oxidative stress and male infertility. Iranian Journal of Reproductive Medicine 2009; 129:357-9.

5. Sepaniak S, Forges T, Gerard H, Foliguet B, Bene MC, Monnier-Barbarino P. The influence of cigarette smoking on human sperm quality and DNA fragmentation. Toxicology. 2006; 223:5460Susanto AD, Prasenohadi, Faisal Y. The year of the lung. Jakarta: Fakultas Kedokteran Universitas Indonesia; 2010.

6. Pavlovic P, Cekic S, Rankovic G, Stoiljkovic N. Antioxidant and pro-oxidant effect of ascocbic acid. Acta Medica Medianae 2005; 44(1): 6569.

7. Hadi L. Efek antioksidan vitamin C dan vitamin E pada cedera kepala trauma berat. Jakarta Medika Kartika 2005;3(1): 366-369
8. Cita I. Pengaruh pemberian vitamin $\mathrm{C}$ terhadap jumlah spermatozoa mencit jantan strain Balb/c yang diberi paparan asap rokok. Skripsi. Semarang: FK Universitas Diponegoro; 2006.

9. Titisari N, Astirin PO, Widiyani T. Pengaruh vitamin $\mathrm{C}$ terhadap perbaikan spermatogenesis dan kualitas spermatozoa mencit (Mus musculus L.) setelah pemberian ekstrak tembakau (Nicotiana tabacum L.). Skripsi. Semarang: Universitas Negeri Semarang; 2003.

10. Siti SU. Pengaruh pemberian vitamin E terhadap proses spermatogenesis mencit jantan strain Balb/c yang diberi paparan asap rokok. Skripsi. Semarang: FK Universitas Diponegoro; 2006.

11. Sari Q. Pengaruh pemberian vitamin E terhadap jumlah spermatozoa dan mencit jantan strain $\mathrm{Balb} / \mathrm{c}$ yang diberi paparan asap rokok. Semarang: FK Universitas Diponegoro; 2006.

12.Iswara A. Pengaruh pemberian antioksidan vitamin $\mathrm{C}$ dan $\mathrm{E}$ terhadap kualitas spermatozoa tikus putih terpapar allethrin. Skripsi. Semarang: Universitas Negeri Semarang; 2009.

13.Ardini DS. Efek pemberian kombinasi vitamin C dan vitamin E terhadap kadar nitric oxide pada preeklamsia. Skripsi. Semarang: FK Universitas Diponegoro; 2005.

14. Kusumawati D. Bersahabat dengan hewan coba. Yogyakarta: Universitas Gadjah Mada. Edisi I:73;2004.

15. Sari VA. Perbandingan efek antioksidan vitamin E dengan selenium dan vitamin E tanpa selenium pada mencit yang diinduksi L_tiroksin. Pekanbaru: Universitas Riau; 2008.

16. Fauzi TM. Pengaruh pemberian timbal asetat dan vitamin $\mathrm{c}$ terhadap kadar malondialdehide dan kualitas spermatozoa di dalam sekresi epididimis mencit albino (Mus musculus L) strain Balb/c.

17.Hosseinzadeh C, Jorsarae GA, Marzony ET. Cigarette smoking and the risk of infertility. Pakistan J; 2007.

18.Sukmaningsih AA. Penurunan jumlah spermatosit pakiten dan spermatid tubulus seminiferus testis pada mencit (Mus musculus) yang dipaparkan asap rokok. Universitas udayana; 2009. 
19.Agarwal A, Dada R, Gupta NP, Kumar R, Malhotra N, Mittal S, Riyaz AM et al. clinical significance of reactive oxygen species in semen of infertile Indian men. Andrologia 2009; 41 (4): $251-6$

20.Agarwal A, Pasqualotto EB, Pasqualoto FF, Sharma RK. Poor semen quality and ROS-TAC scores in patient with idiopatic infertility. Urol Int. 2008; 81 (3): 263-70.

21.Nabil H, Moemen LK, Elela MH. Studying the Levels of Malondialdehyde and Antioxidant Parameters in normal and abnormal human seminal plasma. Australian J. 2008; 2 (3) : 773778.

22.Hayati A. Mangkoewidjojo S. Hinting A. Moedjopawiro S.Hubungan kadar MDA spermatozoa dengan integritas membran spermatozoa tikus (Rattus norvegicus) setelah pemaparan 2-methoxyethanol. J Berk; 2006.

23.Tengku FM. Pengaruh pemberian timbale asetat dan vitamin $\mathrm{C}$ terhadap kadar malondialdehyde dan kualitas spermatozoa di dalam sekresi epididimis mencit albino (Mus musculus $\mathrm{L}$ ) strain Balb/c. Medan: Universitas Sumatera Utara; 2008. 